\title{
IMPROVEMENT OF AN INTEGRATED MANAGEMENT SYSTEM RESULTING IN HIGHER INDUSTRIAL SAFETY EFFICIENCY
}

\author{
M. BEREZYUK ${ }^{1}$, A. RUMYANTSEVA ${ }^{1} \&$ G. CHEBOTAREVA ${ }^{2}$ \\ ${ }^{1}$ Department of Environmental Economics, Ural Federal University, Russia. \\ ${ }^{2}$ Academic department of banking and investment management, Ural Federal University, Russia.
}

\begin{abstract}
LukOIL PermNefteproduct llc management considers industrial and labor safety system as an essential part of efficient production management. Improvement of company's personnel training and further training system in the field of industrial safety, produce quality, workplace health and safety, environmental management as part of integrated management system functioning is the necessary condition of industrial safety management. The educational electronic resource, developed by authors, is the Web-site accessible to all company's employees that consists of guidance and information-reference materials.

Economy effect of the resource usage is cost- and learning time saving, increase of company stuff's competence level.

Keywords: educational electronic resource, industrial safety, integrated management system, labor safety, personnel training.
\end{abstract}

\section{INTRODUCTION}

Relevance of industrial and labor safety issues is undeniable both for the world community and for the Russian Federation.

According to official statistics, 2.34 million people die because of industrial accidents and professional diseases every year. According to International Labor Organization, global economy loses up to $4 \%$ of gross domestic product due to professional injuries and diseases, deaths, worktime fund loss, payments of guarantees and compensations. Nowadays, International Labor Organization resolutely took the course to globalization of tendencies of labor safety [1].

About 2000 manmade disasters happen in our country every year, people die. Usually any accident on the hazardous facility is preceded by numerous gross violations.

The research object is the integrated management system (IMS) of LukOIL PermNefteproduct llc, which is one of the largest interregional oil products supply company of LukOIL Group. It is well-known that specifics of large international energy companies' operations are their international market orientation and accordant international standard requirements in labor and environment safety they have to meet. In addition, the Russian Federation energy industry is in top three fields in terms of volume of negative effect to the environment [2].

The decision on IMS implementation in the organization nowadays is more and more widespread and gives a number of undeniable advantages - it helps to promote company on national and international markets, increases trust from investors, insurance and credit organizations. The implementation of IMS happens to be less time-consuming and more economically profitable than the implementation of several parallel systems.

In order to efficiently meet legal and regulatory requirements, LukOIL PermNefteproduct llc created, implemented and supported the integrated management system - The Health, Safety and Environment Management System (further on - HSE Management System) [3]. 
Research objective is improvement of LukOIL PermNefteproduct llc's integrated management system by creation of a new educational electronic resource.

The Company management considers industrial and labor safety system as an essential part of efficient company production management and undertakes obligations in management of production risks that influence employees' life and health, inventory and property.

It is worth noting that industrial safety level directly depends on qualification of employees working at hazardous facility. Low level of service staff qualification is often the reason for emergency situations. That's why it is essential for organizations that work at hazardous facilities to pay special attention to personnel training. These enterprises must systematically provide employees with training on rules of industrial safety.

At the same time, the integral part of any management system is enterprise's requirement to define needs in personnel training, to provide training and to assess its results, to raise level of knowledge and expertise in industrial, labor and environmental safety.

In order to achieve the given objective we solved further issues:

- analyzed International Organization for Standardization statistics data on ISO certification in the Russian Federation and in the world, analyzed IMS structure varieties at facilities;

- studied the dynamics of employees' industrial injuries and professional diseases rate in the Russian Federation, volumes of funding for preventive measures aimed at industrial injuries and professional diseases reduction in 2008-2015;

- run a general audit check and analysis of LukOIL PermNefteproduct llc's IMS;

- defined basic barriers and complications in the functioning process of LukOIL PermNefteproduct llc integrated management system;

- developed an educational electronic resource for Company's employees;

- created a platform for its allocation.

\section{DYNAMICS OF FACTORS THAT CHARACTERIZE THE LEVEL OF INDUSTRIAL AND LABOR SAFETY IN THE RUSSIAN FEDERATION}

The status of labor conditions and safety directly depends on specifics of country's economic development. Nowadays we see harsh competition between organizations, issues of efficient spending become the priority, and in this context labour conditions and safety are downplayed.

Among factors that characterize the level of industrial and labor safety only industrial injuries rate has positive dynamics given at the diagram (Fig. 1) [1, 4].

Frequency rate of industrial injuries is also falling down (number of accident victims per 1000 workers): $2000-5.1 ; 2005-3.1 ; 2010-2.2 ; 2014-1.4 ; 2015-1.3$. Number of deaths due to industrial accidents fell too. 4404 people died in 2000, 3091 people in 2005, 2550 people on 2008, 1456 people in 2014, 1288 people in 2015. Rate of fatal injuries frequency fell: 0.138 in 1995, 0.149 in 2000, 0.124 in 2005, 0.094 in 2010, 0.067 in 2014, and 0.062 in 2015.

Nevertheless, industrial injuries rate is still high and 4-5 times exceeds rates in economically developed countries. Other factors that describe labor conditions and safety don't have such stable lowering tendency.

From 2008 to 2014, proportion of employees working with hazardous labor conditions rose from $26.2 \%$ to $39.7 \%$ and to $39.1 \%$ in 2015 . Within this framework, the fraction of workers with at least one set type of compensations is high. According to Rosstat data, this fraction amounted $41.4 \%$ of workers headcount in 2005, 46.7\% in 2014 and $44.3 \%$ in 2015 [4]. 


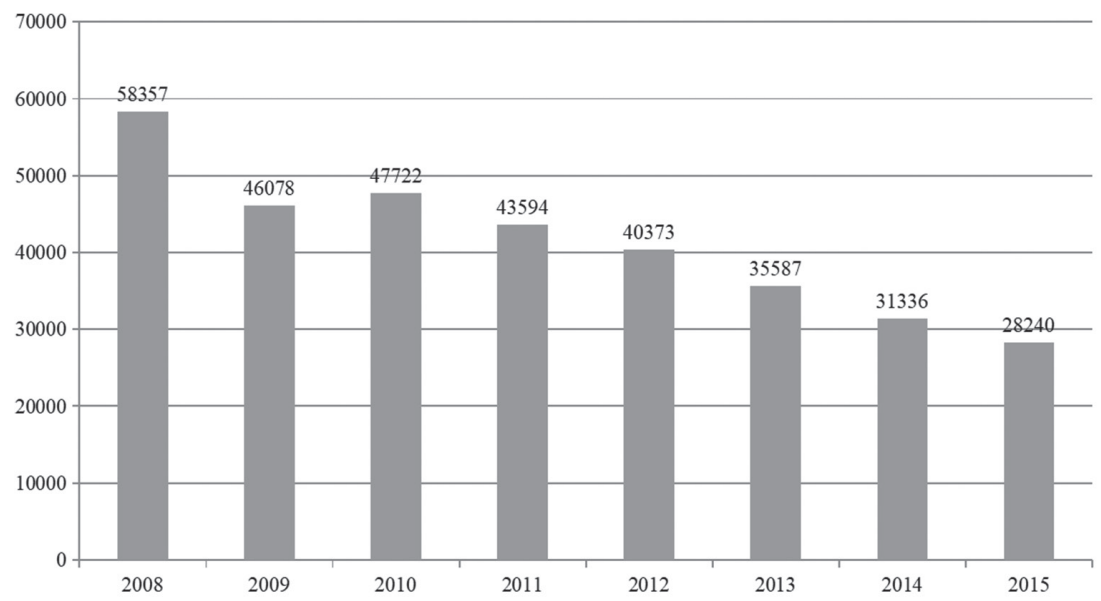

Figure 1: Dynamics of industrial injuries followed by loss of function and death in 2008-2015.

Professional diseases rate doesn't fall (Fig. 2), and chronic diseases (intoxication) prevail in the structure of diagnosed diseases: $98.8 \%$ in 2005 and $93 \%$ in 2014. Number of professional diseases per 10 thousand workers rose: 1.81 in 2000, 2.1 in 2005 and 2.3 in 2015 [5].

At the same time, volumes of funding for preventive measures aimed at industrial injuries and professional diseases reduction rose (according to the RF Social Security Fund data) from 1.2 bln rbls in 2003 to 9.5 bln rbls in 2015 (Fig. 3) [4].

Many efforts were made that focused on labor conditions and safety improvement at the facilities over the last years of economic reforms. But, unfortunately, number of labor safety violations and industrial injuries as a result, are still rather high in comparison to developed countries.

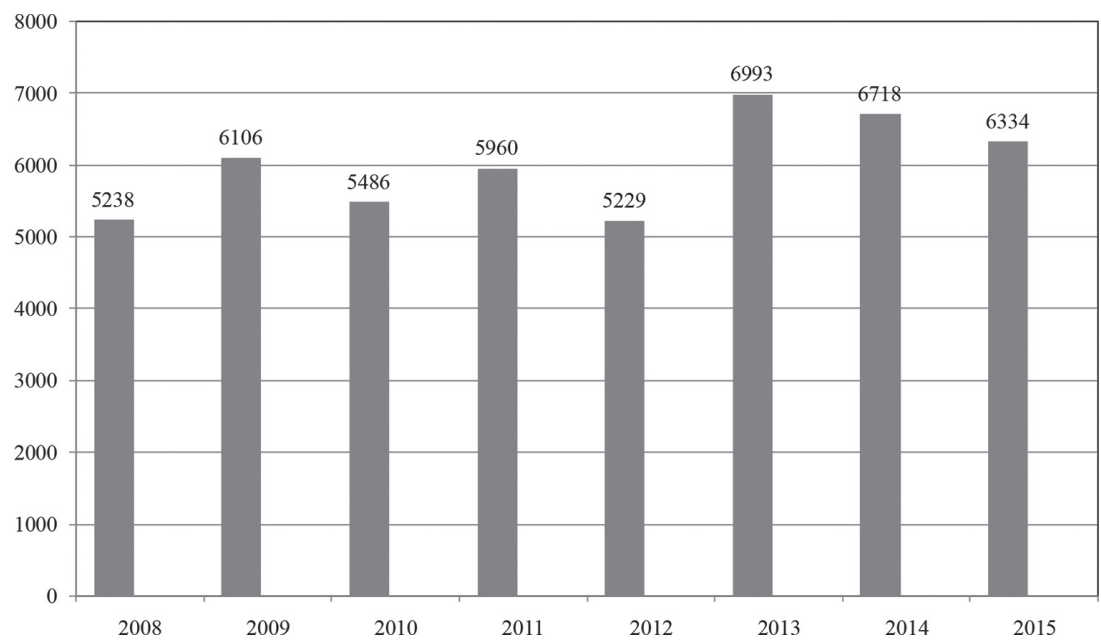

Figure 2: Dynamics of workers' professional diseases in 2008-2015. 


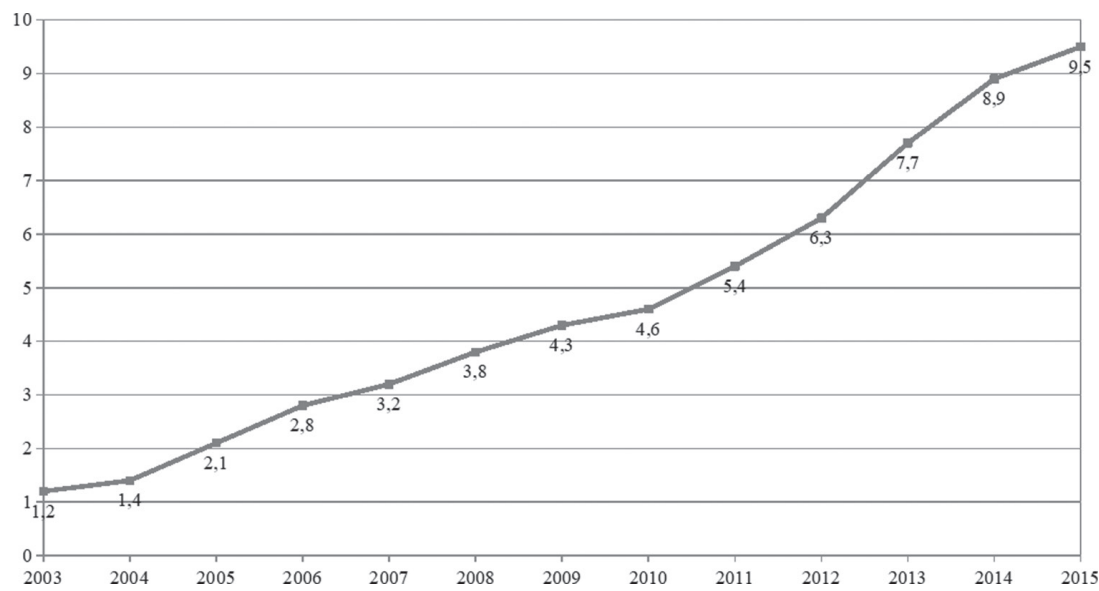

Figure 3: Funding for preventive measures on industrial injuries and professional diseases reduction, billion rubles.

High industrial injuries rate causes losses for businesses and for the government due to loss of working time: according to experts, losses from industrial injuries and compensations for workers in 2015 comprised $107.9 \mathrm{mln}$ resource days, and losses from common industrial injuries $-11.5 \%$. Underproduction of output and services within this framework turns into loss of gross domestic product - about $0.6 \%$. Altogether, economic losses from the state of labor conditions in the Russian Federation comprised 1.29 trn rbls (1.8\% of GDP) $[1,4]$.

Thus, for achievement of higher standards, improvement of labor conditions, increase of industrial and environmental safety level, it is necessary to use the vast experience of economically developed countries with modern legislative systems that set standards and requirements for labor safety issues.

\section{DYNAMICS OF QUANTITY OF ISSUED ISO CERTIFICATES}

Integrated management system is a combination of two or more management systems functioning as a whole. The most widespread components of organizations' integrated management systems in the Russian Federation are:

- quality management system based on ISO 9001:2015 standard (Russia-adapted analogue of the standard is GOST P ISO 9001:2015) [6];

- environmental management system based on ISO 14001:2015 standard (Russia-adapted analogue of the standard is GOST P ISO 14001-2016) [7];

- professional health and safety management system OHSAS 18001:2007 (GOST 12.0.2302007) [8];

and other management systems.

Dynamics of quantity of issued ISO certificates in the Russian Federation is given at Table 1 and Figs 4 and 5 [9].

All the biggest energy companies in Russia implemented and certified EMS; explosive growth of implementations was seen before 2010. Thereat, the employees' motivation for EMS implementation in these companies is practically zero. The ownership of code certificate does not guarantee improvement in environment quality [10]. 
Table 1: The rate of change in the number of issued ISO international standard certificates in the Russian Federation.

\begin{tabular}{lllllll}
\hline Standard/year & 2010 & 2011 & 2012 & 2013 & 2014 & 2015 \\
\hline ISO 9001 & 62265 & 13308 & 12488 & 11764 & 11301 & 9084 \\
ISO 14001 & 1953 & 1093 & 1090 & 1272 & 1263 & 1156 \\
ISO 50001 & - & 1 & 8 & 25 & 81 & 118 \\
ISO 27001 & 72 & 31 & 27 & 48 & 50 & 55 \\
ISO 22000 & 191 & 143 & 171 & 279 & 482 & 733 \\
\hline
\end{tabular}

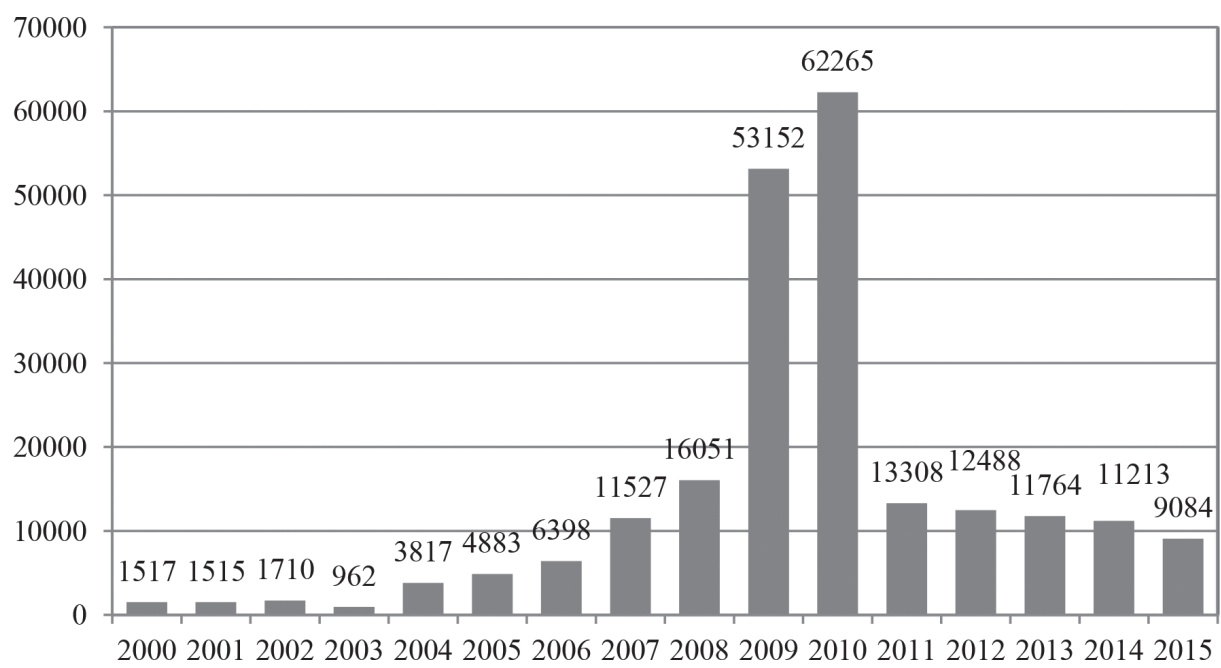

Figure 4: Dynamics of quantity of issued ISO 9001 certificates in the Russian Federation.

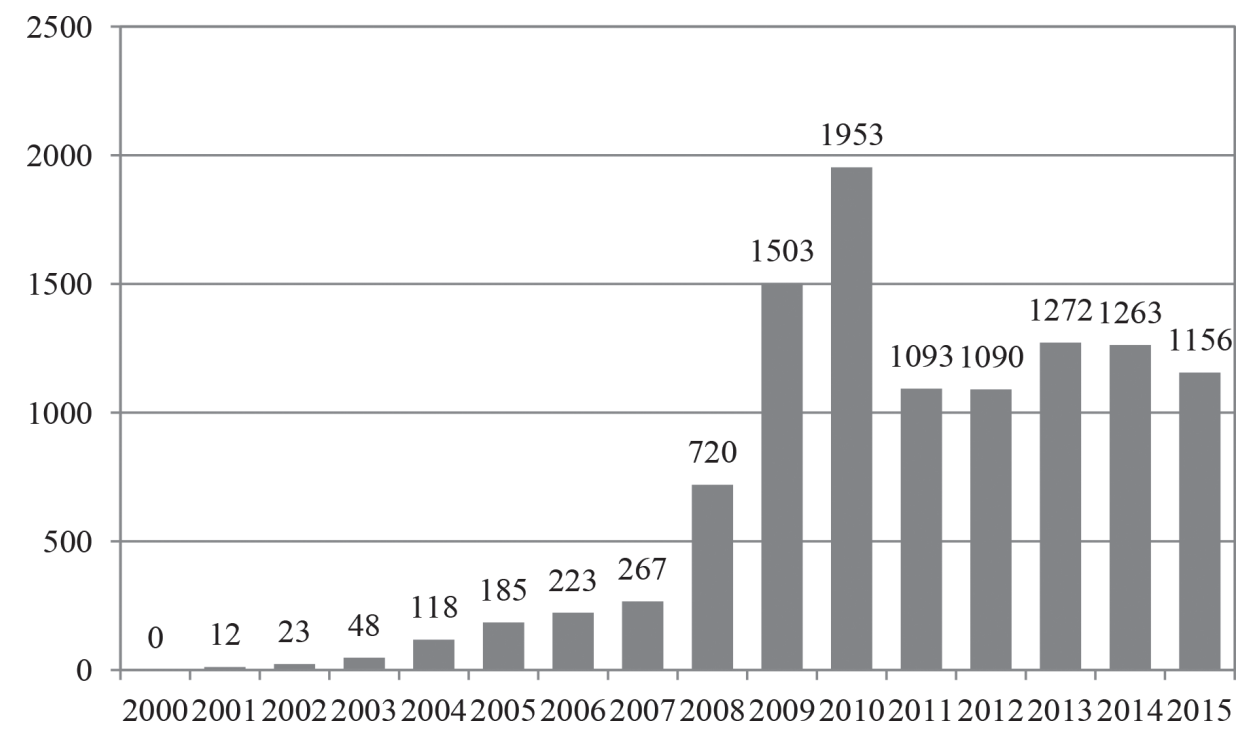

Figure 5: Dynamics of quantity of issued ISO 14001 certificates in the Russian Federation. 
Data analysis of State pollution monitoring in the Russian Federation shows that the pollution load of natural habitats, both in separate factors and in full assessment, is practically unchanged over the last years [11].

Comparison of ISO 14001 certificates quantity per 100000 people of country's population with Environmental Performance Index also doesn't give substantive statistical connection [12].

Data analysis shows that the situation in the Russian Federation corresponds with international trends mostly. There is a drop in ISO 9001 and ISO 14001 standards implementation, but trends of ISO 50001, ISO 27001 and ISO 22000 standards implementation are steady. As it was told before, in order to efficiently meet legal and regulatory requirements LukOIL PermNefteproduct llc created, implemented and supported the integrated management system - Health, Safety and Environment Management System (further on - HSE Management System) [3].

IMS for Storage and Realization of Oil Products activities functions in compliance with requirements of Russian legislation, ISO 14001:2015 'Environmental Management Systems. The Requirements and Usage Guidelines' and OHSAS 18001:2007 'Professional Health And Safety Management System - The Requirements'. Collective results of International Standardization Organization are given in Tables 2, and 3 [9].

A total of 1,036,321 certificates were issued to ISO 9001 (including 4190 issued to the 2015 version published in September 2015) a slight decrease of $0.2 \%$ on last year. A total of 319,324 certificates were issued to ISO 14001 (including 947 issued to the 2015 version published in September 2015) up 8\% on last year. A total of 11,985 certificates for ISO 50001 for energy management were issued (up 77\% on last year) and 3133 certificates issued to ISO 22301 for business continuity management (up $78 \%$ on last year). The strong growth seen for these two standards is likely to be related to the fact that they are both relatively new to the market. ISO and IEC's standard for information security, ISO/IEC 27001 saw a $20 \%$ increase

Table 2: Total number of issued ISO international standard compliance certificates, $\%$ change by year.

\begin{tabular}{lllllll}
\hline Standards & 2010 & 2011 & 2012 & 2013 & 2014 & 2015 \\
\hline ISO 9001 & 1076525 & 1009845 & 1017279 & 1022877 & 1036321 & 1076525 \\
$\%$ & 1 & -6 & 1 & 1 & 1 & $-0,2$ \\
ISO 14001 & 239880 & 243393 & 260852 & 273861 & 296736 & 319324 \\
$\%$ & 8 & 1 & 7 & 5 & 8 & 8 \\
ISO 50001 & - & 459 & 2236 & 4826 & 6765 & 11985 \\
$\%$ & - & - & 387 & 116 & 40 & 77 \\
ISO 27001 & 15626 & 17355 & 19620 & 21604 & 23005 & 27536 \\
$\%$ & 21 & 12 & 13 & 10 & 6 & 20 \\
ISO 22000 & 18580 & 19351 & 23278 & 24215 & 27690 & 32061 \\
$\%$ & 34 & 8 & 20 & 4 & 14 & 16 \\
ISO 13485 & 18834 & 19849 & 22317 & 25655 & 26280 & 26255 \\
$\%$ & 15 & 5 & 12 & 15 & 2 & $-0,2$ \\
ISO 16949 & 43946 & 47512 & 50071 & 53723 & 57950 & 62944 \\
$\%$ & 7 & 8 & 5 & 7 & 8 & 9 \\
ISO 22301 & - & - & - & - & 1757 & 3133
\end{tabular}


Table 3: Countries with the most ISO international standard certified companies in 2015.

\begin{tabular}{|c|c|c|c|c|c|c|c|c|}
\hline \multirow[b]{3}{*}{ Country } & \multicolumn{8}{|c|}{ International standards/Amount of the certificates } \\
\hline & ISO & ISO & ISO & ISO & ISO & ISO & ISO & ISO \\
\hline & 9001 & 14001 & 50001 & 27001 & 22000 & 13485 & 16949 & 22301 \\
\hline China & 292559 & 114303 & 262 & 2469 & 9949 & 1961 & 25498 & 3 \\
\hline Italy & 132870 & 22350 & 470 & 1013 & 818 & 2635 & 1345 & 17 \\
\hline Japan & 47101 & 26069 & 44 & 8240 & 1089 & 1064 & 1482 & 200 \\
\hline Spain & 32730 & 13310 & 390 & 676 & 590 & 379 & 959 & 51 \\
\hline Germany & 52995 & 8224 & 5931 & 994 & 256 & 2508 & 3473 & 27 \\
\hline $\begin{array}{l}\text { United } \\
\text { Kingdom }\end{array}$ & 40161 & 17824 & 1464 & 2790 & 121 & 1651 & 629 & 345 \\
\hline Russia & 9084 & 1156 & 118 & 55 & 733 & 125 & 329 & 0 \\
\hline USA & 33103 & 6067 & 53 & 1247 & 210 & 5231 & 4345 & 40 \\
\hline France & 27844 & 6847 & 500 & 227 & 669 & 1400 & 1012 & 8 \\
\hline Total & 1033936 & 319324 & 11985 & 27536 & 32061 & 26255 & 62944 & 3133 \\
\hline
\end{tabular}

to 27,536 certificates worldwide, while ISO 22000 for food management and ISO/TS 16949 for the automotive sector were up $16 \%$ and $9 \%$, respectively.

This year we added a new management system standard, ISO/IEC 20000-1:2011 Information technology - Service management - Part 1 Service management system requirements, after recommendations from international accreditation and certification experts that we consult annually. This brings the total of standards surveyed to 9. A total of 1,519,952 certificates were issued worldwide in 2015, compared to 1,476,504 the previous year, an increase of $3 \%$.

There is not much information on OHSAS 18001 influence in the world. In particular, according to information, published at British Standards Institute (BSI) web-site, OHSAS 18001 was used in 16,000 organizations in 80 countries in 2005. 54,000 OHSAS 18001 certificates in 116 countries were used in 2009. There is no summarized data on the Russian Federation shared.

There are also translation problems, even in the terms area. There is no 'labor safety' term in the world practice, where 'occupational safety and health' or 'occupational health and safety' terms are used, that might be translated in Russian verbatim as 'production (industrial) safety and health'. There is no such word as 'labor' in English terminology. 'Safety' in Russian means 'security', 'occupational' - 'professional'. In literal translation in Russian 'professional security'. This term is close in its meaning with 'industrial safety', because it means emergence of highly dangerous situations and relates not only to production, but to all the economy branches [13].

Regarding problems of OHSAS 18001 implementation, it is worth to note the existence of different interpretations of Standard requirements by different independent assessment officers - certification authorities that perform independent audit. Some difficulties still appear while building of an integrated management system based on OHSAS 18001, ISO 9001 and ISO 14001, but these three standards are mostly compatible. These problems probably will be solved when OHSAS will become an ISO standard, because now all the management system standards of International Standardization Organization have unified form and, as much its specifics allow, unified contents. 
As is well-known, new ISO 9001:2015 and ISO 14001:2015 standards were approved in 2015. The structure and terminology of ISO 14001:2015 significantly differ from the previous version. These changes were introduced for better integrated implementation of management systems' standards in the same organization and to implicate uniform procedure management consistent with quality, environmental, labor safety requirements [14-16].

Although, the implementation of ISO 14001 standard's new version in the nearest time might become a serious challenge for Russian businesses due to specifics of national environmental legislation, poor development of environmental infrastructure and technologies, weariness of basic environmental funds; all of these require preliminary preparations at the strategic management level. Particular complications of adaptation to new basic requirements involve the Russian certified organizations' need to implement such environmental management instruments as assessment and management of product/service's life cycle, environmental performance indicators, multistakeholder dialogue, organization's context analysis, managers' leadership, records management, process and risk-oriented approaches to management [17].

Additionally, publication of new ISO 45001 standard is expected in summer of 2017; it will be the first ISO standard for labor safety management systems. ISO/DIS 45001 consists of requirements for basic parties of interest and is built on widespread OHSAS 18001 specifications. OHSAS implementation in Russia broadly corresponds to the world practice. And identity of GOST P 54934-2012 and OHSAS 18001:2007 allows companies to take part in international economic activities [18].

Therefore, the necessity and importance of personnel training improvement, generation of personnel knowledge and new competencies are particularly acute at the stage of standards update and necessity of organizations' certification according to the new standards.

\section{RESEARCH METHODOLOGY}

In order to assess efficiency of The Health, Safety and Environment Management System at LukOIL PermNefteproduct llc, the HSE Management System audit is performed every year. The questionnaire survey of Company's facilities was proposed as the audit method. 12 facilities, based in Yekaterinburg and the Sverdlovsk region (15\% of all facilities), were audited (with questionnaire) in 2014.

Based on audit results, authors concluded that Company's personnel don't have a full comprehensive idea of environmental culture and Company's Policy, basic documents that concern providing industrial and environmental safety. Workers and specialists don't understand the importance of their specialization and the ability to make adjustments to the existing system, they are not aware of environmental aspects [19].

Moreover, only 57 (out of 574) employees of the Sverdlovsk regional department completed training in industrial and environmental safety in 2014, what comprises only $9.9 \%$ of department personnel.

All of the aforesaid defines importance and necessity of improvement of such integrated management system element as personnel training. In order to improve the situation in the Company, authors developed an educational electronic resource for all levels of personnel to acquire required professional competences within existing IMS, with special focus on environmental management system.

There is a vast classification of education types, forms and methods; each of them with a variety of advantages and disadvantages.

The traditional education is classroom activities where teacher's work is aimed mostly at delivery of knowledge and methods of operation, given to the students in prepared form, and 
intended for reproducing learning. The teacher is the only proactive side of educational process. Bases of this education were laid almost four centuries ago by Y.A. Komenskiy (The Great Didactics). Such education form is still the most widespread.

Remote learning is an educational technology carried out mostly with the help of IT networks and with mediated (at a distance) interaction between students and teachers (Federal law № 273-FZ ‘On Education in the Russian Federation' from 29.12.2012). One of the types of remote learning is relatively new type - e-learning.

E-learning is transfer of knowledge and management of education process with the help of new information and communication technologies. Interactive electronic tools of information delivery are used in the process of e-learning, usually the Internet and companies' corporate networks, but other ways are possible, too, for example, CDs.

New information technologies implementation into the process of education is directed to activation of learning process, learning speed increase, rise of time for learner's individual and independent study. E-learning usage in education has lots of advantages and it is a widespread trend in world educational community. Let's take a closer look at advantages and disadvantages of e-learning.

E-learning advantages are:

- no temporal constraints for learning;

- learning flexibility, broad reach and mobility;

- high quality of training sessions (based on the usage of multimedia tools);

- usage of multimedia tools: texts, sounds, pictures, videos, animation;

- availability for all ranks of learners;

- broad geography of training;

- teacher-student interaction;

- physical presence of teacher and students in the classroom is not necessary;

- reduction of travel time and costs for students;

- no classroom rent expenses;

- ability to teach a large amount of students at the same time;

- ability to register students' activities and academic progress;

- ability to create different education models.

\section{E-learning disadvantages are:}

- it requires skills of Internet usage, which is not available for everyone and, inversely, requires other expertise;

- overdependence on technologies;

- lack of teacher-student interaction;

- nonexistence of face-to-face communication;

- inadequate attention to mass communications;

- lack of practical activities;

- low level of participation in educational process.

The basic principle of integrated management system functioning is participation of all employees and departments in the work of the system. So, the IMS policy must be reported to every employee, but often it is too complicated for understanding in the written form and requires thorough studying; therefore, the company employees must have a special set of professional objective competences. 
All the standards comprised in IMS have relevant clauses on employees' awareness, necessity of providing within-the-company accessibility to any information that might be relevant for providing personnel safety. IMS implementation allows carrying out unified policy within the company, using resources optimally, creating common personnel training system.

All the institutions provide obligatory briefings and trainings on labor and industrial safety. Top managers and specialists that are responsible for management system creation, support and improvement take obligatory training courses at certified consulting centers. The training is provided in order to create among company's employees common understanding of terminology and standard requirements taken as the base for integration. Training of employees, responsible for creation and implementation of IMS must be taken before the start of these operations and procedures.

\section{DEVELOPMENT OF EDUCATIONAL ELECTRONIC RESOURCE}

As a part of the research, in order to improve the element of training, awareness and competence of LukOIL-Permnefteproduct employees, it was decided to develop an educational electronic resource for Company's employees and to create a platform for its allocation. This software solution includes further sections - basics of industrial safety; operations with chemicals and petrochemicals; organization of safe gas hazardous works; operations with hazardous waste; introduction to environmental management; further training in environment protection, etc.

Training may be provided by scaled programs according to the level of employee's involvement in IMS operations. Several blocks may be allocated: for top managers, for experts (auditors) in internal audit (inspections), for engineers and for workers. Providing consultations, seminars and trainings with the help of outside experts would be too costly because of large number of company's employees, which is not profitable for the company. Therefore it is more rational and efficient to create EER (educational electronic resource), which can solve the assigned issues and improve LukOIL Permnefteproduct's integrated management system with minimal costs.

Educational electronic resource is an automated learning system which includes methodic and informational materials on issues of LukOIL Permnefteproduct's integrated management system functioning $[3,20,21]$.

EER is an assembly of Web pages with shared theme, design, interconnected with hyperlinks system, located in the Internet; in other words, EER is the Web site. It has hypertext structure which allows trainee define optimal way to study material with comfortable tempo. This software solution is designed for acquaintance with Health, Safety and Environment Management System (HSE Management System).

Educational electronic resource contains 5 structural elements [19]:

1. The homepage section gives the information on the resource, its target audience, course objectives and proposed outcome, Fig. 6;

2. The 'PJSC LukOIL Policy' section - a fundamental document of integrated management system which includes intentions and principles of the Company on issues of industrial, labor and environmental safety. The section gives abstracts from the Policy, users may also read the full version of the document by clicking hyperlink, Fig. 7;

3. The 'Health, Safety and Environment Management System'section gives the description of HSE Management System activities, Fig. 8;

The 'Industrial safety' subsection gives definitions of 'industrial safety', 'accident', sets types of industrial safety activities, liabilities of the company working at hazardous facility. 


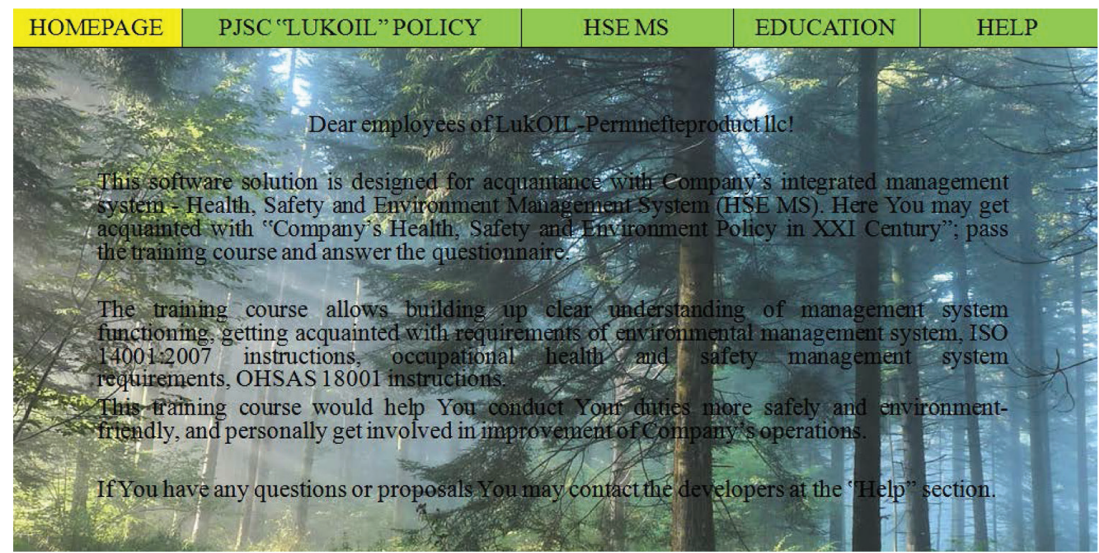

Figure 6: The homepage of educational electronic resource.

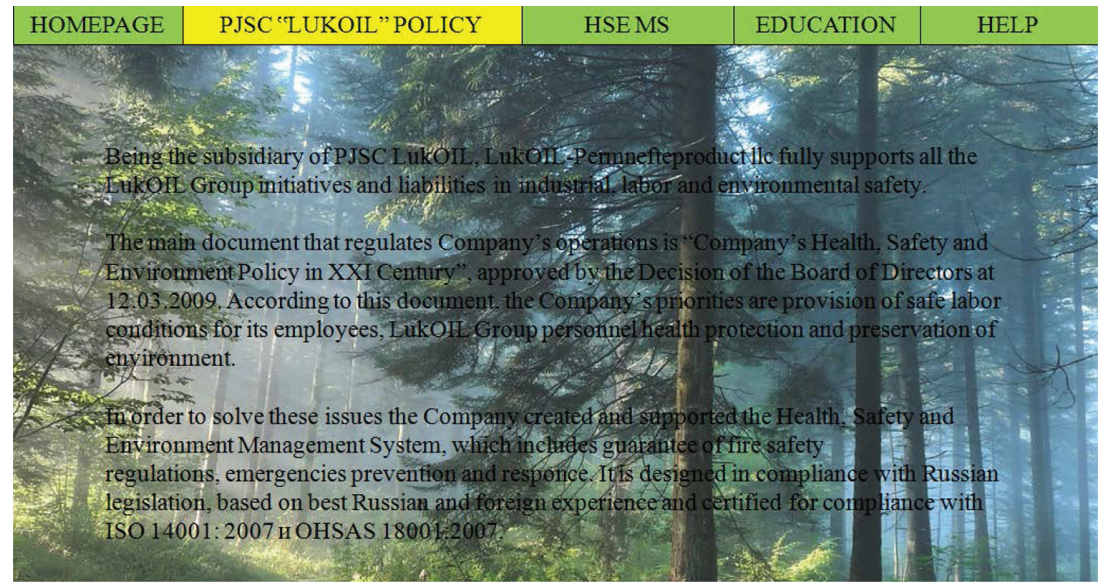

Figure 7: The 'PJSC LukOIL Policy' section of educational electronic resource.

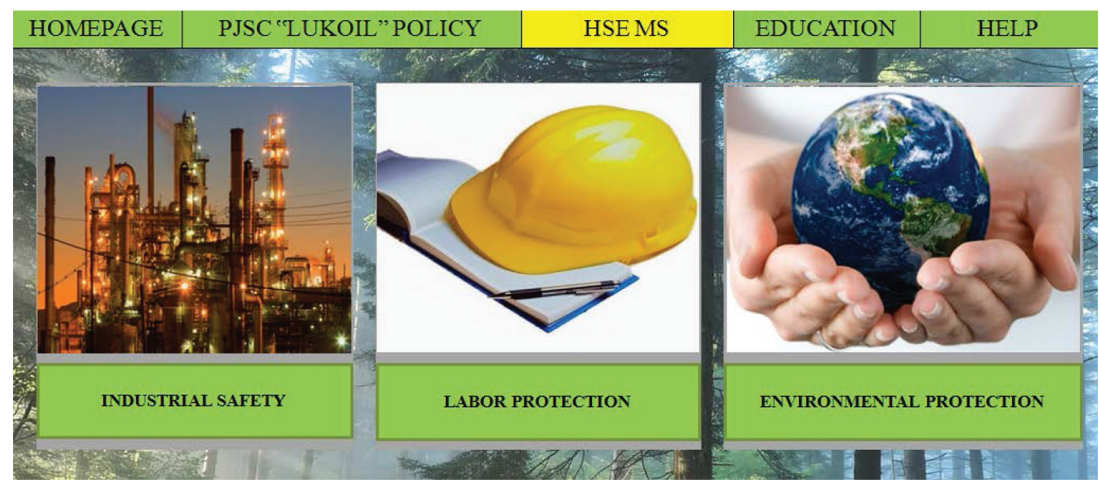

Figure 8: The 'Health, Safety and Environment Management System' section of educational electronic resource. 
The 'Labor Protection' subsection gives definition of 'labor safety', sets the components of labor safety system, employer's liabilities in providing safe labor conditions, workers' rights and liabilities in labor safety.

The 'Environmental Protection' subsection gives definition of 'environmental safety', sets company's strategic goals in provision of environmental safety, gives company's environmental policy and information on significant environmental issues.

4. The 'Education' section consists of 2 training courses on HSE Management System for different levels of qualification: for top-managers and specialists and for other company employees.

Targets, contents, volume and evaluation criteria of training courses differ.

When employee passes the final test, he/she fills in his/her personal data: last name, first name, position held.

The program forms the list of 20 questions for the test; answering time shouldn't exceed 40 minutes. All the questions are numbered and have a description according to the question type (the only correct answer, several correct answers, match the answers, etc.). If the examinee has complications with choosing the right answer, he/she may switch to the next question. All the unanswered questions can be found in 'The List' menu.

When the test if over, statistics data appears on the screen, it shows the score of correct answers, required score for a positive mark, time spent on the test and test results.

The report on test results is emailed to the trainee and the trainer, who makes sure that all the company's employees have passed the course.

5. The 'Help' section gives recommendations in case of difficulties' occurrence while browsing the web-site or passing the training course. Trainer's contacts are also shown at this page, so as the feedback form.

Educational electronic resource is available for all the Internet users, which is one of the requirements of international standards of employees' information support.

\section{ANALYSIS OF THE RESEARCH RESULTS}

There are other forms of education at the company within the existing environment management system. Specific accidents are thoroughly studied and sorted out, corresponding protocols are drawn up, than the management draws up a conclusion and develop new instructions, if unavailable. Beyond that, of course, the company provides opportunities for information exchange and studies the experience of accidents at other holding subsidiaries. After that, the management draws up appropriate protocols and orders adapted to our company.

In order to optimize the personnel training process at LukOIL Permnefteproduct llc, two forms of training were proposed: vocational (with day release) and remote (e-learning without day release).

Top managers and specialists that are responsible for management system creation, support and improvement take 72-hours-or-more training courses at certified consulting centers, with exclusive requirements for acquired knowledge assessment. Other company employees (specialists that don't work with IMS, workers) take training with the help of educational electronic resource during the first month of placement or assumption of the office.

Therefore, the integration of two types of training - day release seminars for top and midlevel managers, responsible for IMS functioning; and e-learning for other employees, - allows boosting company's management system performance and efficiency, and cutting costs for personnel training. 
The training course passing allowed company's employees to understand:

a) Importance of compliance with company policy on industrial, labor and environmental safety, IMS procedures and requirements;

b) Significant environmental aspects, dangers and professional risks and related actual and potential exposure to environment and human health;

c) His/her liabilities and responsibility for reaching compliance with integrated management system;

d) Possible after-effect of breaking set procedures.

\section{CONCLUSIONS}

The manufacturing enterprise that created its own integrated management system must perform regular checks of all the system components along with routine check of specific production processes and provide employees with appropriate knowledge of industrial safety and environmental management.

The software solution is designed for acquaintance with company's Industrial, Labor and Environmental Safety Management System. It allows employees to build up clear understanding of management system functioning, to get acquainted with requirements of environmental management system, ISO 14001:2015 instructions, occupational health and safety management system requirements, OHSAS 180016:2007 instructions.

At the moment, it is too early to make conclusions about actual results of improvement of any indicators of industrial safety due to EER usage, because the usage time elapsed does not give objective information. This aspect will definitely be assessed and analyzed in our upcoming works.

Personnel training on recommended practices of safe production process operations, including environmental safety, with the help of EER-based educational programs on industrial, labor and environmental safety, allow reaching these main results for Company's operations:

- training time reduction;

- training cost reduction;

- more accurate and precise performance of duties;

- decrease of employees' industrial injuries and health damage;

- decrease of compensations;

- increase of employees' working efficiency.

The analysis of internal audit checks shows that elaborate personnel training allows decreasing amount of violations detected amid increased number of checks, which further proves the only thing - increase of efficiency of the management system and overall company management.

Audits help to control whether the system was correctly implemented at the enterprise and will be supported in a proper manner, whether the enterprise follows requirements and norms of management system international standards, how efficiently this system supports company's goals and objectives realization and performance improvement.

In the long run, it would allow defining the state of the company's management system, its principles implementation in everyday operations and efficiency and operability of given formed system. 


\section{REFERENCES}

[1] Rumyantseva, A. \& Samarskaya, N., Labor safety issues: foreign experience. Labor Safety in the Industry, 6, pp. 16-21, 2016.

[2] Berezyuk, M. \& Rumyantseva, A., A concept of transition to the best available technology as a basis for sustainable development of power industry. International Journal of Sustainable Development and Planning, 10, pp. 635-649, 2015.

https://doi.org/10.2495/sdp-v10-n5-635-649

[3] Zhomayko, O. \& Berezyuk, M., Optimization of company's personnel training process within integrated management system improvement. Proceedings of the 9th International Conference, Environmental safety management system, pp. 196-200, 2015.

[4] The report of the Russian Federation Ministry of Labor and Social Protection 'On realization of state policy on labor conditions and safety in the Russian Federation in 2014' [Digital source]. available at: http://www.rosmintrud.ru/docs/mintrud/salary/24.

[5] State report 'On the Condition of Population Sanitary and Epidemiological Welfare in the Russian Federation in 2015' [Digital source], available at: http://24.rospotrebnadzor.ru/documents/ros/147604.

[6] National standard of the Russian federation, [in Russian], Quality management systems. Requirements. [Digital source]. available at: http://docs.cntd.ru/document/1200124394.

[7] National standard of the Russian federation, [in Russian], Environmental management systems. Requirements with guidance foruse. [Digital source]. available at: http://www. pqm-online.com/assets/files/pubs/translations/std/iso-14001-2015-(rus).pdf.

[8] National standard of the Russian federation, [in Russian], Occupational safety standards system. Occupational safety and health management systems. General requirements. [Digital source]. available at: http://docs.cntd.ru/document/gost-12-0-230-2007-ssbt.

[9] The ISO Survey. [Digital source], available at: http://www.iso.org/iso/home/standards/ management-standards.

[10] Itkin, B., Environmental management systems certification and quality of environment. Ecology of Production, 6, pp. 32-41, 2015.

[11] State report 'On the State and Environmental Protection of the Russian Federation in 2015 ' [Digital source]. available at: http://www.mnr.gov.ru/regulatory/detail. php?ID=286341

[12] 2014 EPI Results. Yale University, 2015 [Digital source]. available at: http://epi.yale. edu/epi/country-rankings

[13] Azarov, V., Alimov, N., Gotlib, Y., Mashkova, A. \& Spasova, E., Analysis of GOST 12.0.230-2007 terminology from the perspective of current system of labor safety management. Internet Herald of VSASU. Polythematic series, 1(10), pp. 1-7, 2010.

[14] Khoroshavin, A., The new version of ISO 14001 standard. Ecology of Production, 3, pp. 40-43, 2015.

[15] Itkin, B., About the new version of ISO 14001 standard. Ecology of Production, 3, pp. 46-53, 2016.

[16] Golubeva, S., Strelnikov, Y. \& Cokornova, T., Environmental management system: new version of the standard. Ecology of Production, 9, pp. 40-46, 2016.

[17] Slavinskiy, D., Khoroshavin, A. \& Smirnova, M., Analysis of new international requirements for environmental management systems within situation in Russia. NRU ITMO Scientific Magazine. Economics and Environmental Management Series, 4, pp. 335341, 2015. 
[18] GOST P 54934-2012/OHSAS 18001:2007 Labor Safety Management Systems. Requirements. [Digital source]. available at: http://gostrf.com/normadata/1/4293789/4293789191.pdf

[19] Berezyuk, M., Rumyantseva, A. \& Chebotareva, G., Improvement of the integrated management system of energy companies by the implementation of electronic educational resources. WIT Transactions on Ecology and the Environment, 250, pp. 11-20, 2016.

[20] Jomayko, O. \& Berezyuk, M., Process of company's personnel training with functioning integrated management system. Western Siberia Academic Magazine, 57(2), pp. 89-90, 2015.

[21] Kuznetsova, A. \& Berezyuk, M., Environmental management system as economic and standard regulator of companies operations. Western Siberia Academic Magazine, 57(2), pp. 90-91, 2015. 